\title{
G-fibers and Florin ring-like structures in Dioon (Zamiaceae)
}

\section{Andrew P. Vovides ${ }^{1}$ and Sonia Galicia}

Botanical Sciences

94 (2): 263-268, 2016

DOI: $10.17129 /$ botsci.274

\section{Abstract}

Cuticle information and epidermal characters have great potential in systematic studies. However, micromorphology and anatomical studies on cycads are relatively scarce in comparison to similar studies on other gymnosperms. In this study leaflet anatomy and cuticles in the genus Dioon have been investigated with bright field microscopy, epifluorescence, and scanning electron microscopy. Structures hitherto not completely studied for the genus are reported such as lignified hypodermis, girder sclerenchyma, especially G-fibers, and Florin ring-like structures associated with the stomatal apparatus.

Key words: anatomy, cuticles, cycads, Cycadales, leaflets.

\section{Fibras-G y estructuras de anillo tipo Florin en Dioon (Zamiaceae) \\ Resumen}

La información de cutículas y caracteres epidérmicas tienen gran potencial para estudios sistemáticos. Sin embargo, la micromorfología y estudios anatómicos en las cícadas son relativamente escasos en comparación de estudios similares con otras gimnospermas. En este estudio se investigó la anatomía de foliolos y cutículas del género Dioon con técnicas de microscopia de campo claro, epifluorescencia y de microscopía electrónica de barrido y se reportan estructuras no completamente estudiadas antes para el género. Se observó hipodermis lignificada, presencia de esclerénquima de trabe y particularmente fibras gelatinosas y estructuras semejantes a anillos de Florin asociados con los aparatos estomáticos.

Palabras clave: anatomía de foliolos, cícadas, cutícula, Cycadales.
Instituto de Ecología, A.C.

Xalapa, Veracruz, Mexico

${ }^{1}$ Author for correspondence: andrew.vovides@inecol.mx 


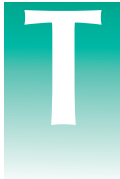

he importance of cuticular information and systematic value of epidermal characters has been emphasized by Stace (1965) who did extensive work on of about 250 species of angiosperms. However micromorphology and anatomical studies on living cycads have been scarce and patchy in comparison to the work done on other gymnosperms i.e. Araucaria de Jussieu (Stockey and Taylor, 1978), Podocarpaceae (Stockey, 1982; Stokey et al., 1998, 1992; Mill and Schilling, 2009) among others since the classical works of Florin cited by Yoshie and Sakai (1958). Early work on cycad leaflets by Lamb (1923) and Papadopoulos (1928) described anatomy of selected species of nine genera and that of a hybrid cycad respectively. Work by Pant and Nautiyal (1963) described cuticle and epidermis of 59 species and Tang et al. (2004) described the leaflet anatomy of ten species from six genera. Mickle et al. (2011) studied the cuticular micromorphology with the scanning electron microscope (SEM) of five species of Cycas L. and drew taxonomic conclusions regarding the status of $C$. normanbyana $\mathrm{F}$. Muell.

The present study is part of a leaflet anatomical study of the Neotropical cycad genus Dioon Lindl., and we report cuticular and anatomical features hitherto unexplored throughout the genus.

Transverse (TS) sections were taken from the mid portion of leaflets that were in turn taken from the mid section of healthy mature leaves from the 14 known species of Dioon held in the Mexican National Cycad Collection held at the Clavijero Botanic Garden, Xalapa. For observation with clear field microscopy sectioning was done using standard microtechnique (Johansen, 1940; Purvis et al., 1966) on fresh or fixed material histochemical staining done with phloroglucinol $\mathrm{HCl}$ for lignin and Sudan III and IV for suberin and cutin. Permanent slides were prepared by double staining with safranin and fast green FCF and mounted in Histoclad ${ }^{\circledR}$. For SEM observations of outer cuticular surfaces, cuticular peels were prepared using a modified technique with Jeffery's solution according to Stace (1965) to obtain clean surfaces as well as untreated material in order to preserve wax deposits, both dried in a desiccator and sputter coated with gold-palladium at $1.5 \mathrm{kv}$ at $5 \mathrm{~mA}$ for eight minutes with a Jeol Fine Coat JFC 1100 sputter coater. Observations were made with a Jeol JSM-5600LV scanning electron microscope.

Transverse sections (TS) of the Dioon leaflets under clear field microscopy revealed thick adaxial cuticles ranging over nine $\mu \mathrm{m}$ in thickness depending on species, lignified epidermis

Figure 1. Dioon leaflet transverse sections. A) Leaflet stained with phloroglucinol- $\mathrm{HCl}$ to show lignified hypodermis and girder sclerenchyma (red), note hyaline G-fibers with lignified wall (arrow). Bar: $100 \mu \mathrm{m}$. B) Double stained with safranin and fast green-FCF, note G-fibers cellulose secondary wall (S3) green, lignified outer wall (S1 and S2) red (arrow). Bar: $20 \mu \mathrm{m}$. C) Young leaflet showing hyaline fibers with lesser thickening of secondary wall (arrows). Bar: $40 \mu \mathrm{m}$. D) Stomatal apparatus of D. purpusii stained with Sudan III and IV showing thickened periclinal wall of raised encircling cell, thick cuticle (arrow) and cuticular papillae protruding into the stomatal chamber. Bar: $20 \mu \mathrm{m}$. E) Abaxial epidermal surface of $D$. edule under epifluorescence microscopy showing thickened cuticle surrounding pores forming Florin rings (arrow). Bar: $20 \mu \mathrm{m}$.

\section{A}
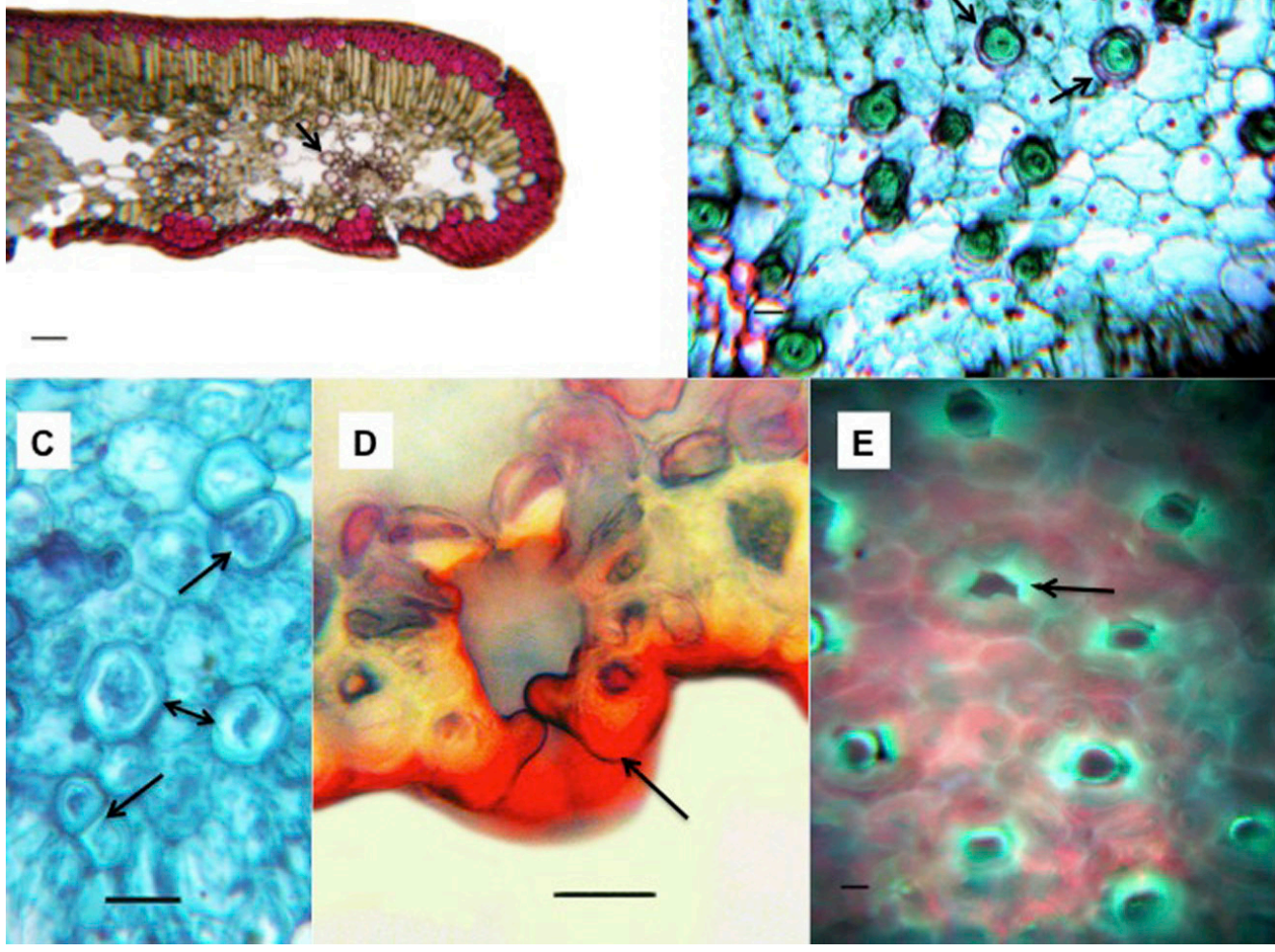
and hypodermis with girder sclerenchyma varying in layers according to species (Figure 1A). Thick walled non-lignified hyaline fibers with virtually no lumen are interspersed between the hypodermis and the single row of palisade mesophyll as well as in the spongy mesophyll (intervascular) and surrounding the vascular bundles (perivascular) were observed in mature leaflets of all species. These have been referred to as bast fibers (Lamb, 1923); and bast cells (Papadopoulos, 1928). These are now known as tension wood fibers or gelatinous fibers (G-fibers) and have been reported for cycads by Tomlinson et al. (2014) associated in the secondary phloem in roots that undergo contraction, in Gnetum; and in angiosperms by Fisher and Blanco (2014). Gfibers are not restricted to wood or angiosperms and may have originated during an early period of spermatophyte evolution (Tomlinson et al., 2014).

In mature leaflets of Dioon these fibers appear gelatinous-like, the first layers of the secondary wall (S1 and S2 layers) react for lignin with phloroglucinol- $\mathrm{HCl}$ forming a lignified sheath (Figure 1A). The rest of the secondary wall (S3 layer) does not and stains with fast green. The thick cellulose S3 layer often breaks away during sectioning that is a characteristic of G-fibers (V. Angyalossy pers. com.) being rich in cellulose and stains green when double stained with safranin and fast green (Figure $1 \mathrm{~B}$ ). The hyaline fibers of young leaflets (three to four weeks after emergence) do not show these characteristics differing by having a much less thick cellulose secondary wall with a large lumen (Figure 1C).

G-fibers or gelatinous fibers are commonly found in tension wood that forms in response to gravitational stresses. They may be clustered together forming compact tension wood or as single fibers or in small groups forming diffuse tension wood (Mauseth, 1988). G-fibres are poor in lignin but rich in cellulose (Coté et al., 1969; Mauseth, 1988) and have a complex chemical structure (Bowling and Vaughn, 2008).

In healthy, mature and functioning leaflets of Dioon they appear to be single fibers dispersed within the spongy mesophyll and closely clustered around the vascular bundles in varying numbers. Most cycad leaves and leaflets tend to be very coriaceous, heavy but flexible and long lived, especially in Dioon where the leaflets are strongly reinforced by a lignified hypodermis and girder sclerenchyma that adds weight to the leaf. These cycads grow in exposed environments such as rocky outcrops on steep hills or on canyon walls that are exposed to wind and direct sunlight. Thus they are exposed to mechanical stress and water loss through transpiration. In D. edule leaf flushes occur every other year (Chamberlain, 1919; Vovides, 1990) and the life span of any given leaf in the field may be up to three years or more (pers. obs.). It is likely that once the long lived leaves of Dioon have reached maturity, usually less than three to six months after emergence, aspects such as flexibility, resistance to mechanical stress and the water absorbing ability of the G-fibers would thus offer some advantage to the plants occupying these harsh environments. Future research should follow the development and quantification of these fibres from early leaf emergence through to senescence.

All Dioon spp. are hypostomatic and the adult stomatal apparatus consists of three layers of encircling cells above the subsidiary cells forming an epistomatal chamber that varies in depth according to species. In TS through the stomatal apparatus a prominent thickening of the periclinal wall and cuticle of the outer or distal encircling cells occurs, forming a raised ring around the epistomatal pore. This can be seen when stained with Sudan III and IV (Figure 1D) and is reminiscent of Florin rings, for want of a better term. Florin rings are associated with the subsidiary cells observed in both living and fossil gymnosperms such as Pinus strobus by Deckert et al. (2001), Papuacedrus (Wilf et al., 2009) and in Falcatifolium (Podocarpaceae) by Stockey et al. (1992). In Dioon these structures can also seen under epifluorescence microscopy of the abaxial cuticular surface using 400-440 nm exciter filters (Figure 1E) comparable to the Florin rings reported by Wilf et al. (2009) on fossil Papuacedrus and Paull and Hill (2010) on fossil Cupressaceae. Dilcher (1969) describes Florin rings as "conspicuous thickened rings of cutin overlying the accessory cells and surrounding the stomata."

In the stomata of Dioon the situation differs in that there are three layers of encircling cells above the subsidiary (accessory) cells, that together form a deep stomatal chamber. The outermost (distal) encircling cells have a thickened upper periclinal wall as well as a thickened cuticle and can be seen in the transverse section of the Sudan stained cuticle in figure 1D (arrow) also under fluorescence microscopy in figure 1E (arrow) and illustration (Figure 2). Another 
Figure 2. Illustration showing section through stomatal apparatus of Dioon purpusii showing thickened cuticle (black), $\mathrm{G}=$ guard cell, $\mathrm{S}=$ subsidiary cell, $\mathrm{E}=$ encircling cells. Bar: $20 \mu \mathrm{m}$.

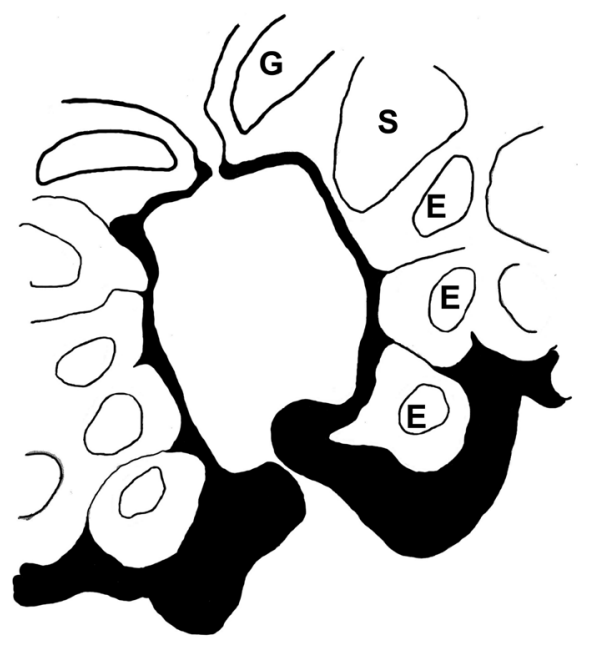

difference is that stomatal plugs, as reported for Podocarpaceae by Stockey et al. (1992), were rarely seen in Dioon but present occasionally.

The strongly overarching papillate subsidiary cells reported for Cycas revoluta by Pant and Mehra (1964) are unlike the structures in Dioon though their ontogeny may be similar; figure $1 \mathrm{G}$ in Pant and Mehra (1964) shows an overarching papilla of a subsidiary cell in a young stoma, and another subsidiary cell dividing to give rise to one encircling cell, and their figure $3 \mathrm{~F}$ an adult stoma overarched by thickened papillae of subsidiary cells. In Dioon it is the outermost of the three layers of encircling cells with thickened periclinal wall and cuticle that forms the Florin ring-like ring structure.

SEM observations of the cuticle surface of the stomatal band of mature leaflets for all species show a variably undulating surface marking the outline of the epidermal cells. The epistomatal apertures appear raised by the encircling cells forming variably marked structures with regular,
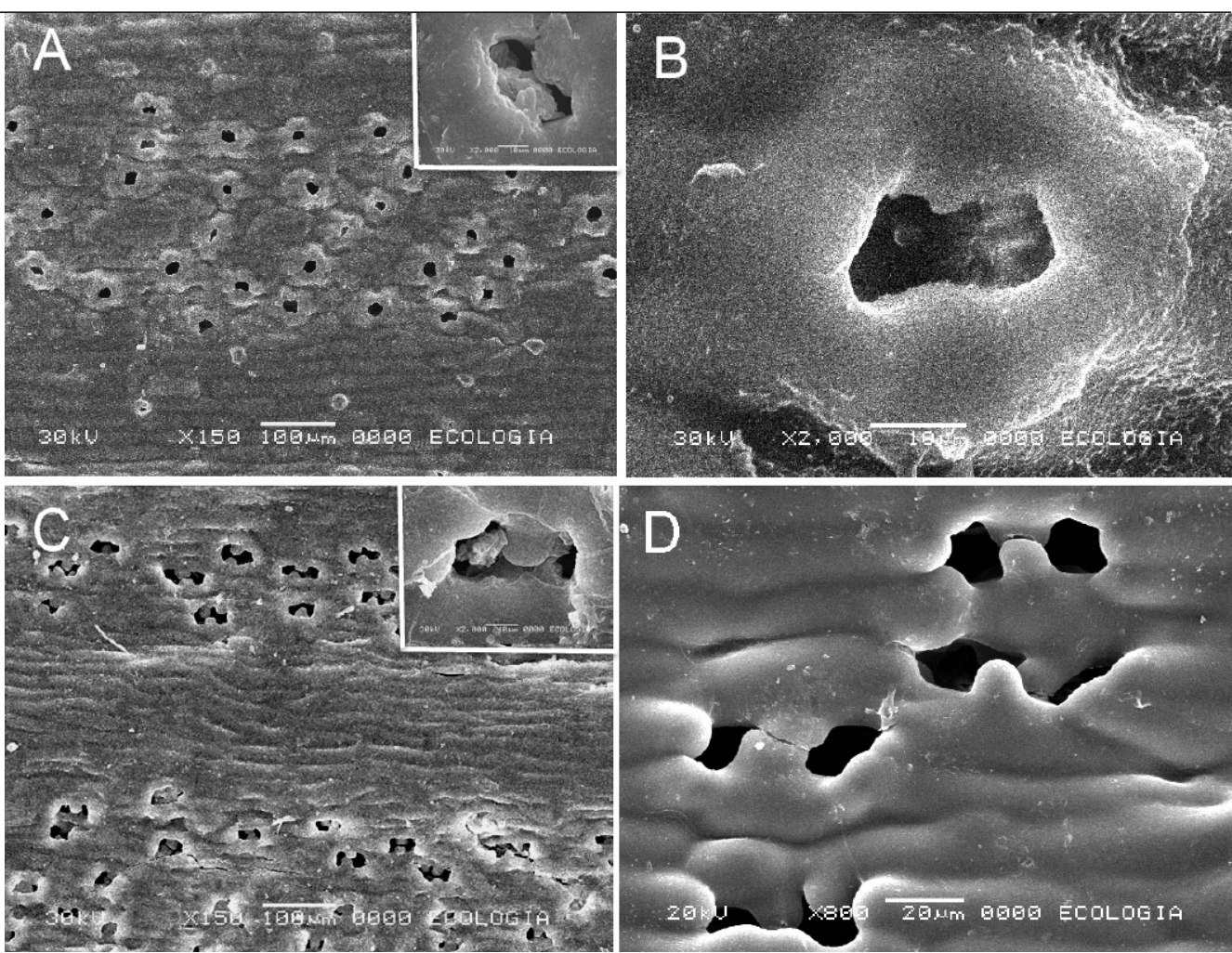
irregular or slight relief and outline according to species. We observe two types; (1) the Dioon edule Lindl. type (Figure $3 \mathrm{~A}$ ) that is a continuous raised ring that slightly overarches the stomatal pore resulting in a volcanic shape that corresponds to the Florin ring type $\mathrm{C}$ of Yoshie and Sakai (1985), wax plugs sometimes referred to as Florin plugs have also been observed but are not common (Figures 3A insert and 3B); (2) the D. purpusii Rose type (Figure 3C) some presenting wax plugs (Figure $3 \mathrm{C}$ insert) that also corresponds to the type $\mathrm{C}$ ring but contrasts with the D.edule type as irregularly undulating with protruding papillae that vary in number and position, at times partially obscuring the stomatal pore (Figure 3D). The stomatal papillae vary in number, position and depth in the stomatal chamber within and between species that present the $D$. purpusii type structure.

\section{Acknowledgements}

We thank the Jardín Botánico Fco. J. Clavijero for the living cycad material used for this study and Vernonica Angyalossy for revising some of our microscopical preparations and for her comments. This research was financed by SEP-CONACyT project No. CB-2011-01-169468. The authors also thank two anonymous reviewers whose comments and suggestions have greatly improved the manuscript.

\section{Literature cited}

Bowling A.J. and Vaughn K.C. 2008. Immunocytochemical characterization of tension wood: gelatinous fibers contain more than just cellulose. American Journal of Botany 95:655-663.

Chamberlain C.J. 1919. The living cycads. Hafner, New York.

Coté W.A. Jr., Day A.C. and Timell T.E. 1969. A contribution to the ultrastructure of tension wood fibers. Wood Science and Technology 3:257-271.

Deckert R.J., Melville L.H. and Peterson R.L. 2001. Epistomatal chambers in the needles of Pinus strobus L. (Eastern white pine) function as microhabitat for specialized fungi. International Journal of Plant Sciences 162:181-189.

Dilcher D.L. 1969. Podocarpus from the Eocene of North America. Science 164:299-301.

Fisher J.B. and Blanco M.A. 2014. Gelatinous fibers and variant secondary growth related to stem undulation and contraction in a monkey ladder vine, Bauhinia glabra (Fabaceae). American Journal of Botany 101:608-616.

Lamb M.A. 1923. Leaflets of the Cycadaceae. Botanical Gazette 76:185-202.

Johansen D.A. 1940. Plant Microtechnique. McGraw-Hill, New York.

Mauseth J.D. 1988. Plant Anatomy. The Benjamin/Cummins Publishing Company Inc., Menlo Park.

Mickle J.E., Barone Lumaga M.R., Moretti, A. and De Luca P. 2011. Scanning electron microscopy studies of cuticle micromorphology in Cycas L. (Cycadaceae). Plant Biosystems 145:191-201.

Mill R.R.. and Stark Schilling D.M. 2009. Cuticle micromorphology of Saxegothaea (Podocarpaceae). Botanical Journal of the Linnean Society 159:58-67.

Paull R. and Hill R.S. 2010. Early Oligocene Callitris and Fitzroya (Cupressaceae) from Tasmania. American Journal of Botany 97:809-820.

Pant D.D. and Mehra B. 1964. Development of stomata in leaves of three species of Cycas and Ginkgo biloba L. Journal of the Linnean Society (Botany) 58:491-497.

Pant D.D. and Nautiyal D.D. 1963. Cuticle and epidermis of recent cycadales leaves sporangia and seeds. Senckenbergiana Biologica 44:257-347.

Papadopoulos S. 1928. A morphological comparison of leaflets of a hybrid cycad and the two parents. Botanical Gazette 85:30-45.

Purvis M.J., Collier D.C. and Walls D. 1966. Laboratory Techniques in Botany. Butterworths, Washington D.C.

Stace C.A. 1965. Cuticular studies as an aid to plant taxonomy. Bulletin of the British Museum Natural History (Botany) 4:1-78.

Stockey R.A. 1982. The Araucariaceae an evolutionary perspective. Review of Palaeobotany and Palynology 37:133-154.

Stockey R.A., Ko H. and Woltz P. 1992. Cuticle morphology Falcatifolium De Laubenfels (Podocarpaceae). International Journal of Plant Sciences 153:589-601.

Stockey R.A., Frevel B.J. and Woltz P. 1998. Cuticle morphology of Podocarpus, subgenus Podocarpus, section Scytopodium (Podocarpaceae) of Madagascar and South Africa. International Journal of Plant Sciences 159:923-940. 
Received:

October 9th, 2014

Accepted:

March 2nd, 2015
Stockey R.A. and Taylor T.N. 1978. Cuticular features and epidermal patterns in the genus Araucaria de Jussieu. Botanical Gazette 139:490-498.

Tang Y.J., Liu N., Liao J.P., Xie Z.Y., Wu Q.G. and Chen J.R. 2004. Systematic implications of pinna venation and pinna anatomy in Zamiaceae. Acta Phytotaxonomica Sinica 42:365-374.

Tomlinson P.B., Magellan T.M. and Griffith M.P. 2014. Root contraction in Cycas and Zamia (Cycadales) determined by gelatinous Fibers. American Journal of Botany 101:1275-1285.

Vovides A.P. 1990. Spatial distribution, survival and fecundity of Dioon edule (Zamiaceae) in a tropical deciduous forest in Veracruz, Mexico, with notes on its habitat. American Journal of Botany 77:15321543.

Wilf P., Little S.A., Iglesias A., Zamaloa M. del C., Gandolfo M.A., Cúneo N.R. and Johnson K.R. 2009. Papuacedrus (Cupressaceae) in Eocene Patagonia: a new fossil link to Australasian rainforests. American Journal of Botany 96:2031-2047.

Yoshie F. and Sakai A. 1985. Types of Florin rings, distributional patterns of epicuticular wax, and their relationships in the genus Pinus. Canadian Journal of Botany 63:2150-2158. 